\title{
TOURISTS' MOTIVATIONS TO TRAVEL: A THEORETICAL PERSPECTIVE ON THE EXISTING LITERATURE
}

\author{
Anish Yousaf \\ Insha Amin \\ Jose Antonio C. Santos
}

\author{
Review \\ Received 10 May 2017 \\ Revised 4 July 2017 \\ 28 March 2018 \\ Accepted 13 April 2018
}

https://doi.org/10.20867/thm.24.1.8

\begin{abstract}
Purpose - Current study is an attempt to look into the various theoretical concepts/ theories that help to understand what motivates individuals, especially young people, to travel and which are the practical implications of the analysed theories. In particular, we chose Maslow's Theory of Needs to analyse youth travel motivations.

Research Design - The study draws its base from two streams of literature, one being associated with motivations and the other dealing with the question of how motivations can influence travelling patterns of an individual. The literature review was done extensively and articles published in the domain of tourist motivations and related areas were traced and reviewed.

Findings - Our analysis of youth tourism centred on Maslow's hierarchy of needs and confirmed its validity as an explanation of the most important youth travellers' motivations. The results also indicate that, due to recent technological developments affecting societies and young tourists' behaviours - especially those of Millennials - new needs have emerged, which are discussed in detail.

Research Limitations - The research has been carried out in light of the available literature and it fails to address empirical evidence. Also, the analysis of youth tourism needs to be extended to other motivation theories as those which are presented in this work.
\end{abstract}

Keywords tourism, motivation, tourist, pull factor, push factor, destination.

\section{RESEARCH BACKGROUND}

Tourism is currently one of the most dynamic phenomena worldwide. The travel and tourism industry has grown by leaps and bounds over the years, with international tourist arrivals recorded as 1,235 million for 2016, thereby accounting for 3.9\% of global economic growth for that year (United Nations World Tourism Organisation [UNWTO], 2016). Tourism as an activity must contend with a wide range of tourist behaviours and the internal or external forces that significantly influence these behaviours. This industry is regarded as particularly vibrant, and it includes travelling for the purposes of pleasure, relaxation, visits to friends and family, pilgrimages and other related activities.

Li and Zhang (2013) and Simkova and Holzner (2014) report that individuals' travel patterns are closely related to psychological patterns, which can be used to examine the factors that motivate people to travel. Hill (1965) early on explored vacationers' motives as a response to psychosomatic exhaustion. They seek to replenish and restore their sense 
Tourism and Hospitality Management, Vol. 24, No. 1, pp. 197-211, 2018

A. Yousaf, I. Amin, J.A.C. Santos: TOURISTS’ MOTIVATIONS TO TRAVEL: A THEORETICAL

of wellbeing, as well as explore new ways to enrich, regenerate and recharge their lives. Crompton (1979) later defined motivations as only one of many contributing factors that inspire individuals to travel to different places and experience new things (Um \& Crompton, 1992).

In his landmark study, Dann (1981) confirmed that tourists' state of mind influences them to travel and visit new places. Thus, understanding the drives that motivate tourists to travel can benefit marketers in quite significant and positive ways (Uysal \& Hagan, 1993). Crompton (1979) and Todorovic and Jovicic (2016) argue that the core reason for going on holidays is that individuals look for a break from their usual schedule and settings that allow them to relax and lessen mental fatigue.

Despite much research focusing on tourists' motivations to travel, more studies are still needed to explore the various theoretical foundations that form the basis of researchers' understanding of travel patterns. The present study, therefore, sought to contribute to the existing literature by bringing together various motivational theories of tourism through a literature review and examining their contributions to understanding travellers' behaviours. More specifically, this research included an analysis of youth travellers' needs and motivations using the most heavily cited motivation theory - Maslow's hierarchy of needs. This theory can be regarded as the seminal motivational theoretical framework from which the most important tourist motivation theories have evolved.

\section{LITERATURE REVIEW}

As suggested by Uysal et al. (2008), we used Fodness's (1994) definition of motivation as the driving force behind all behaviour. Many previous studies have focused on tourists' motivations to travel, including, among others, Plog (1974), Dann (1977, 1981), Crompton (1979), Ahola (1982), Beard and Ragheb (1980, 1983), Virdi and Traini (1990), Baloglu and Uysal (1996), Uysal and Jurowski (1994), Klenosky (2002), Snepenger et al. (2006), Biswas (2008), Ancuta et al. (2011) and Simková (2013).

The literature related to youth travellers' motivations was extensively reviewed in order to gain an in-depth understanding of this phenomenon. However, for greater ease of communication, only articles in English were considered for this study. The guidelines for collecting secondary data developed by Cooper (1984) were followed as these have been applied by many other researchers seeking to develop conceptual or theoretical frameworks. The literature reviewed for the present study was extracted by using secondary sources of information and applying the approach proposed by Cooper (1984).

The current literature review was thus conducted using various journals (i.e. the ancestry approach) in order to cover different sources of information related to this study (i.e. relevant articles and their citations) (Cooper, 1989). Numerous powerful databases were used to find studies on tourist motivations and youth travel, including EBSCO, Scopus and Thompson Reuters Web of Science, thereby ensuring that the most important journal publications on these topics were reviewed. 
Tourism and Hospitality Management, Vol. 24, No. 1, pp. 197-211, 2018

A. Yousaf, I. Amin, J.A.C. Santos: TOURISTS' MOTIVATIONS TO TRAVEL: A THEORETICAL ...

\section{Understanding Youth Travellers' Motivations}

The UNWTO's 2016 Annual Report confirmed the importance of youth travel, stating that it 'has become one of the fastest-growing segments of international tourism representing more than $23 \%$ of tourists travelling internationally each year' (UNWTO, 2016). Richards (2015) also confirmed that the number of youth travellers is increasing. This is in line with tourism growth in general, but young people in many countries around the world have recently acquired more purchasing power (Richards, 2015).

The rapid growth of the young traveller market segment in a globalised world has contributed to a fragmentation of this segment into many youth traveller types. Besides the classic backpackers, many youths can be categorised as travellers, tourists, volunteers, language students, exchange students and interns (Richards, 2015). This diversity may be a consequence of increasing opportunities for mobility. According to (Richards, 2015, p. 341), 'advances in technology have facilitated physical mobility, and more recently the growth of information and communication technology has created more widespread social relations, which has strengthened the tendency towards mobility still further.'

Buffa's (2015, p. 14051) study of young tourists' profiles and attitudes revealed that 'in the choice of destination the motivations considered most important are the discovery of new cultures, discovery of new landscapes, contemplation of natural and artistic heritage, contact with local community, [and] contact with nature'. The cited author goes on to write:

Most young tourists say they prefer local food, adapt as much as they can to the traditions and customs of the place in which they are holidaying, try to learn about their destination before travelling, would be willing to be involved in events organised by the local community and to interact with it, demonstrate interest in the protection of the authenticity of the destination, even if this means going without certain comforts, find out how to protect the local environment and reduce waste, and are concerned to ensure that their spending benefits the local population. (p. 14051)

Based on a large-scale survey (i.e. 34,000 respondents), Richards (2015) identified three large groups of travellers: global nomads, backpackers and flashpackers. Global nomads will most likely seek contact with local people and everyday life at the destination, 'staying in local people's homes and connecting to local communication networks as well as the Internet' (Richards, 2015, p. 348). Backpackers typically travel together with other backpackers from home countries, and these travellers are driven by the desire to wander like nomads might. Backpackers prefer to discover new places in independent and alternative ways and strengthen ties or create new ties with backpacker communities. Finally, according to Richards (2015, p. 348), 'the flashpacker is the most connected traveller, using social media frequently and ... being more likely to mix and blur work and leisure.'

Regarding the use of new information and communication technologies, young tourists represent the highest percentage of those utilising these technologies (Bizirgiannia \& Dionysopouloub, 2013). Young tourists 'participate actively in various productive 
Tourism and Hospitality Management, Vol. 24, No. 1, pp. 197-211, 2018

A. Yousaf, I. Amin, J.A.C. Santos: TOURISTS' MOTIVATIONS TO TRAVEL: A THEORETICAL ...

processes of tourist enterprises, such as the design, development and distribution of new products' (Bizirgiannia \& Dionysopouloub, 2013, p. 652). Thus, these tourists' travel motivations and behaviours are closely connected to the availability of information about destinations on the Internet and in social media, as well as the availability of suitable digital facilities at destinations. These include, for example, good, free Internet connectivity (e.g. in accommodations and attractions) and new technological environments based on innovations.

A recent study by Han et al. (2017) also found evidence that youth travellers are concerned about the environment and are willing to behave pro-environmentally. This means that they express 'intention[s] to engage in sustainable buying behaviours, ... engage in recycling behaviours, and ... protect natural and local resources' (Han et al., 2017 , p. 914). According to the cited authors, a resulting practical implication for destinations is that 'marketers of tourism destinations should actively identify effective ways to ... [satisfy] these individuals' moral obligations to conduct pro-environmental behaviours while traveling' (Han et al., 2017).

Several questions arise from the above findings. One issue is the use of terminology such as 'travellers' and 'tourists'. Traveller is a much broader concept than tourist, as not all travellers are tourists. For instance, some types of travellers referred to by Richards, such as language and exchange students and interns, cannot be considered tourists because their motivation is not travelling for leisure.

Another question is the definition of youth travel, which the above discussion shows is different from youth tourism, including the age delimitation of youth travellers. According to the UNWTO (2008):

Youth travel includes all independent trips for periods of less than one year by people aged 16-29 which are motivated, in part or in full, by a desire to experience other cultures, build life experience and/or benefit from formal and informal learning opportunities outside one's usual environment.

While a definition of youth travel has already been proposed, Dionysopoulou and Mylonakis (2013, p. 23) report that 'youth tourism is not yet recognised by ... government policies as a niche market of [the] travel industry'.

Marketers tend to make a distinction between Generation Y (i.e. Millennials) and Generation Z (i.e. Post-Millennials). The Millennials segment comprises individuals born in the last decades of the twentieth century. Some authors define this as between 1979 and 1994 (Kotler \& Keller, 2012; Santos et al., 2016), while others argue this generation was born between 1980 and 2000 (Alexakis, 2011; Kotler \& Keller, 2012; ITB, 2016). According to these age delimitations, not all Millennials fit in the UNWTO's (2008) aforementioned age frame, but experts agree that they represent the strongest subsegment of youth travellers due to their higher purchasing power.

Millennials have strong digital skills and a high degree of permanent connectivity. They search for authentic and memorable experiences, need to immerse themselves in the lifestyle of local inhabitants and value experiences similar to those of residents and volunteer tourism options. These individuals are increasingly concerned about their 
Tourism and Hospitality Management, Vol. 24, No. 1, pp. 197-211, 2018

A. Yousaf, I. Amin, J.A.C. Santos: TOURISTS' MOTIVATIONS TO TRAVEL: A THEORETICAL ...

health, wellbeing and safety (Veiga et al., 2017). Another important feature of Millennials is that they see travel as a complement to education and a form of personal development (Veiga et al., 2017). The ITB World Travel Trends Report 2016/2017 confirms the importance of European Millennials, who 'went on about 150 million outbound trips in 2015 ' (ITB, 2016, p. 26). This report also states that 'this generation is recognised as having the highest education level compared to all previous generations' (Santos et al., 2016, p. 659).

Academic studies have yet to characterise Generation $\mathrm{Z}$ travellers and their travel motivations fully. However, some non-academic sources discuss this segment, referring to it as the generation born in the last years of the twentieth century and the first decade of the twenty-first century. A clear link exists between these age groups and the age of the booming numbers of Internet and new technologies users, as the individuals of this generation are digital natives.

\section{Application of Motivation Theory to Tourism}

With the travel and tourism industry's expansion, various allied businesses of this industry have experienced a significant and urgent need to identify the most pertinent factors that could have an important impact on tourists' motivations to travel. These firms seek to redesign their offerings accordingly. Understanding the motivational forces behind tourist behaviours could help service providers to augment and adjust their offers to become more appealing to - and hit the right notes for - target tourists.

\section{Maslow's Hierarchy of Needs}

Maslow's (1943) five-level hierarchy of needs remains one of the most broadly accepted theories applied by researchers seeking to understand human behaviour. Due to its vast scope, this theory has often been used in the field of tourism since the hierarchy of needs helps clarify travellers' varied motivations and thereby explain tourists' travel behaviours. The cited theory divides human behaviour into five distinct levels of needs, in which the fulfilment of one need leads to another on a higher level, thus forming a hierarchy. Maslow (1943) named the first set of motives 'physiological needs', which are associated with individuals' basic needs, such as food, shelter and water.

Applying the same concept to the tourism industry, physiological needs are the basic needs that travellers expect destinations to meet. These requirements include various facilities provided to travellers during their stay at destinations, including, among others, suitable accommodations, potable water and restaurants providing good food and/or cuisine. These needs are so basic in nature that they can be regarded fundamental motivations for all travellers (Maslow, 1943).

The second need in Maslow's (1943) motivational pyramid is associated with travellers' safety-related issues. Destinations can attract increasing numbers of visitors only if they provide a safe, secure environment in which travellers feel protected from any threats during their stay. When visitors are convinced that destinations' facilities will remain stable and look after them during their time there, the probability that they will choose 
Tourism and Hospitality Management, Vol. 24, No. 1, pp. 197-211, 2018

A. Yousaf, I. Amin, J.A.C. Santos: TOURISTS’ MOTIVATIONS TO TRAVEL: A THEORETICAL

those destinations is higher. The likelihood of a positive response in the form of tourist inflows will also be stronger for those destinations (Maslow, 1943).

The third need of the cited author's hierarchy refers to forming relationships with people to create a sense of social belonging and confirm their ability to develop healthy relationships. Social belonging plays a clear, positive role in motivating travellers to visit destinations. Individuals tend to travel to specific places to develop strong bonds with family and friends or to become familiar with destinations' local communities.

Once this motivation is satisfied, the fourth motivation arises, which is associated with self-esteem. At this level, people travel in order to impress friends, relatives, social groups and other people and to gain higher social status (Maslow, 1943). The final need in the hierarchy is self-actualisation. Travellers see tourism as an activity through which they can improve their special skills by doing something that is quite challenging to these individuals. Self-actualisation in tourism can also be related to activities in which people get involved in doing something that benefits society (Maslow, 1943).

\section{Dann's Theory of Push and Pull Motivations}

The push and pull theory of motivations proposed by Dann (1977) is another widely accepted theoretical framework in tourism research. According to Dann (1997), multiple factors motivate tourists and/or travellers to visit particular places or destinations, but these factors can be categorised as either push or pull motivations.

Push factors can, at the most basic level, be explained as intrinsic factors or internal drives that urge individuals to travel. These are associated with factors such as longings for rest, recreation, adventure and escape and a desire to 'get away from it all' and to transcend the feeling of isolation inherent in contemporary lifestyles. Thus, push factors can be summed up as factors encouraging people to travel, representing individuals' socio-psychological needs. In contrast, pull factors are mostly associated with destinations' amenities, for example, service quality, prices and infrastructure.

While applying these factors in the context of tourism, researchers have observed that push factors are more inward in nature and physiological. When exploited by destination planners and marketers in appropriate ways, these factors can help attract more tourists to particular destinations. Push factors that are adequately understood and exploited by destination planners in appropriate ways can then become pull factors, which are mostly external in nature.

Pull factors come from within destinations, but these factors can help trigger push factors. Destinations thus should be able to meet customers' expectations in terms of prices, facilities (e.g. accommodation, transportation, food, restaurants and amusement parks) and, most importantly, the level of quality provided. This means that, from time to time, destination managers need to augment their offers in ways that satisfy customers' needs and desires. 
Tourism and Hospitality Management, Vol. 24, No. 1, pp. 197-211, 2018

A. Yousaf, I. Amin, J.A.C. Santos: TOURISTS' MOTIVATIONS TO TRAVEL: A THEORETICAL ...

\section{Travel Career Ladder (TLC)}

Based on Maslow's (1943) five-level hierarchy of needs, Pearce (1988) proposed the TCL model, which lists five travel motivations associated with relaxation, stimulation, relationship, self-esteem and development or fulfilment. According to the cited model, travel motivations fall into two categories: needs that are self-centred and motivations that are directed at others. Pearce (1988) reports that recreation can be a self-initiated exercise - in which individuals seek out quiet, restful time alone - or relaxation - in which people go on holidays in the company of others. The latter springs from the need for external excitement and a desire for novelty.

The second travel motivation, as described by Pearce (1988), is associated with stimulation and is self-directed, arising from individuals' concern for their safety and security. This motivation can also be directed towards others, arising out of worries about others' wellbeing. The third travel motivation refers to relationships, and it can be selfdirected, which means maintaining relationships, or directed at others, which means bonding with others and developing emotional attachments to friends or family.

The fourth travel motivation comprises self-esteem and personal development. This is either self-directed, including enhancing skills, hobbies, proficiencies and expertise, or this motivation may be directed at others, such as quests to acquire social status or the allure associated with those who travel to certain destinations. The last factor, fulfilment, is completely self-directed as it fulfils individuals' dreams and focuses strongly on the contentment people feel after finding peace with their inner self (Pearce, 1988).

\section{Travel Career Patterns (TCP)}

One of the most important theoretical frameworks based on Maslow's hierarchy of needs is the TCP model developed by Pearce and Lee (2005). The TCP model is mostly constructed along the same lines as the TCL approach. TCL theory suggests that travellers' progress up the ladder of travel motivations as their level of travel experience increases, while TCP theory sees these motivations as a complex and dynamic process that comprises many levels at the same time. The concept of a travel career is central to the TCP, as is the idea that travellers' behaviours reflect changing motivational patterns during their travel careers (Pearce \& Lee, 2005).

The TCP is centred on 14 motivational factors:

1) Self-actualisation - internal

2) Self-enhancement - internal

3) Romance - internal

4) Belonging - internal

5) Autonomy - internal

6) Self-development (i.e. host site involvement) - external

7) Nature - external

8) Escape/relax - most important

9) Novelty - most important

10) Kinship - most important

11) Nostalgia - less important 
12) Stimulation - less important

13) Isolation - less important

14) Recognition and/or social status - less important

These factors play an extremely important role in determining motivations that drive individuals to travel to distant places and influence travellers' decision-making processes (Pearce \& Lee, 2005). Table 1 summarises some of the most frequently cited motivation theories in tourism research.

Table 1: Summary of Tourist Motivation Theories

\begin{tabular}{|c|c|c|c|}
\hline $\begin{array}{l}\text { Author } \\
\text { (Year) }\end{array}$ & Theory Name & $\begin{array}{c}\text { Citations } \\
\text { (as of 18th } \\
\text { Feb., 2018) } \\
\end{array}$ & Contribution \\
\hline $\begin{array}{l}\text { Maslow } \\
\text { (1943) }\end{array}$ & $\begin{array}{l}\text { Hierarchy of } \\
\text { needs } \\
\text { theory }\end{array}$ & 23,831 & $\begin{array}{l}\text { - Explains that human behaviour } \\
\text { is the outcome of various needs } \\
\text { that occur in a hierarchal order } \\
\text { and the fulfilment of one need } \\
\text { leads to an awareness of the } \\
\text { next level of need } \\
\text { Provides a better } \\
\text { understanding of how human } \\
\text { needs are a crucial underlying } \\
\text { factor in any context }\end{array}$ \\
\hline $\begin{array}{l}\text { Cohen } \\
(\mathbf{1 9 7 2})\end{array}$ & Types of tourists & 941 & $\begin{array}{l}\text { - Classifies tourists based on their } \\
\text { travel behaviours and groups } \\
\text { them as 1) organised mass } \\
\text { tourists, 2) individual mass } \\
\text { tourists, 3) explorers and 4) } \\
\text { drifters }\end{array}$ \\
\hline $\begin{array}{l}\text { Dann } \\
(\mathbf{1 9 7 7})\end{array}$ & $\begin{array}{l}\text { Push and pull } \\
\text { theory of tourist } \\
\text { motivation }\end{array}$ & 1,662 & $\begin{array}{l}\text { - Builds a theoretical framework } \\
\text { based on two concepts: anomie } \\
\text { and eco-enhancement. } \\
\text { - Defines the anomie factor as the } \\
\text { desire to transcend feelings of } \\
\text { isolation, while eco-enhancement } \\
\text { derives from personal needs }\end{array}$ \\
\hline $\begin{array}{c}\text { Crompton } \\
\text { (1979) }\end{array}$ & $\begin{array}{l}\text { Socio- } \\
\text { psychological } \\
\text { motivations to } \\
\text { travel }\end{array}$ & 3523 & $\begin{array}{l}\text { - Identifies seven socio- } \\
\text { psychological motives and two } \\
\text { cultural motives that drive } \\
\text { individuals to travel }\end{array}$ \\
\hline $\begin{array}{c}\text { Iso-Ahola } \\
(\mathbf{1 9 8 2})\end{array}$ & $\begin{array}{l}\text { Social psychology } \\
\text { model of tourism }\end{array}$ & 1338 & $\begin{array}{l}\text { - Based on push and pull effects, } \\
\text { asserts that personal escape and } \\
\text { search and interpersonal escape } \\
\text { and search motivate tourism and } \\
\text { recreation } \\
\text { Combines the main elements (i.e. } \\
\text { escape and reward) depending on } \\
\text { the particular situation and } \\
\text { tourists' goals }\end{array}$ \\
\hline
\end{tabular}


Tourism and Hospitality Management, Vol. 24, No. 1, pp. 197-211, 2018

A. Yousaf, I. Amin, J.A.C. Santos: TOURISTS' MOTIVATIONS TO TRAVEL: A THEORETICAL ...

\begin{tabular}{|c|c|c|c|}
\hline $\begin{array}{c}\text { Author } \\
\text { (Year) }\end{array}$ & Theory Name & $\begin{array}{c}\text { Citations } \\
\text { (as of 18th } \\
\text { Feb., 2018) }\end{array}$ & Contribution \\
\hline $\begin{array}{c}\text { Pearce } \\
(\mathbf{1 9 8 8 )})\end{array}$ & TCL & 697 & 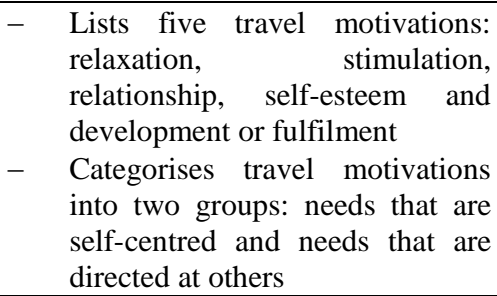 \\
\hline $\begin{array}{c}\text { Pearce } \\
\text { and Lee } \\
(2005)\end{array}$ & TCP & 678 & $\begin{array}{l}\text { - Centres on } 14 \text { motivational } \\
\text { factors: } \\
\text { 1) Self-actualisation - internal } \\
\text { 2) Self-enhancement - internal } \\
\text { 3) Romance - internal } \\
\text { 4) Belonging - internal } \\
\text { 5) Autonomy - internal } \\
\text { 6) Self-development (i.e. host site } \\
\text { involvement) - external } \\
\text { 7) Nature - external } \\
\text { 8) Escape/relax - most important } \\
\text { 9) Novelty - most important } \\
\text { 10) Kinship - most important } \\
\text { 11) Nostalgia - less important } \\
\text { 12) Stimulation - less important } \\
\text { 13) Isolation - less important } \\
\text { 14) Recognition and/or social } \\
\text { status - less important }\end{array}$ \\
\hline
\end{tabular}

Source: Authors

\section{DISCUSSION}

Maslow's (1943) hierarchy of needs clearly inspired Dann's (1981) push and pull theory, Pearce's (1988) TCL and Pearce and Lee's (2005) TCP, moving from a general motivation theory to theories specifically applicable to tourism behaviours. These theories apply to tourists in general. However, these approaches cannot be used to analyse all tourists or even all tourist segments because technology and society have evolved rapidly and new generations with different beliefs and unique travel patterns and motivations have joined tourist flows.

Mobility is easier and more generalised than ever before, and every tourist has his or her own motivations to travel. Some new tourists do not follow traditional travel patterns and even do not accept being called tourists. Countless possibilities exist for mobility motivated by other reasons to travel than tourism, such as student exchange programmes or opportunities to work abroad. The line between tourists and non-tourists has become fuzzy for travellers as a whole because non-tourists may engage in tourism activities, including eating in restaurants and discovering new places. 
Tourism and Hospitality Management, Vol. 24, No. 1, pp. 197-211, 2018

A. Yousaf, I. Amin, J.A.C. Santos: TOURISTS' MOTIVATIONS TO TRAVEL: A THEORETICAL ...

In discussions about travel motivations, the psychology behind travellers' behaviours plays a quite critical role in forming these individuals' overall desire to visit particular destinations. Understanding tourist behaviours and the factors that affect these patterns is crucial to tourism planners' success. According to Uysal et al. (2008, p. 413), '[a]n improved understanding of travel motivations would help in segmenting ... markets, thereby allowing tourism marketers to allocate scarce tourism resources more efficiently.' In this way, planners can create specific products for different segments and promote their offers accordingly. In addition, understanding the travel motivations of various tourist segments and creating better products that satisfy their needs would allow destinations and tourism organisations to create optimal conditions for unforgettable tourism experiences.

Conceptual models such as those examined in the present study are useful to destination marketing organisations and stakeholders, providing clues to how they should design and align their products with the market. These models help decision makers understand the most basic aspects of travellers' motivations, refining how planners perceive travel behaviours and the factors that influence their decision-making processes. Applications of travel motivation theories provide insights into tourist behaviours in particular destinations, including, among other factors, what tourists are searching for, what they want to experience during their vacations, which activities they are looking for and how they want their vacation to turn out overall.

This better understanding of travel motivations can further help destination planners to understand changing patterns of travellers' behaviours and ways these changes have evolved over time. The theories examined here - when mixed with marketing strategies - can facilitate the creation of more appropriate promotional directions and properly aligned approaches, which ensure destinations' offers reach the most suitable and more extensive customer bases.

The existing literature offers clarity regarding consumer motivations, revealing why individuals behave as they do. Researchers have reached a consensus about these motivations' continuing significance in consumer decision-making processes and these factors' relevance to marketing practices. Through motivational theories, travellers' basic behaviours have been elucidated, and a clearer theoretical understanding of travel motivations has been achieved.

Regarding Maslow's (1943) hierarchy of needs, the present study highlighted that, once one need of a traveller is satisfied, the next, higher need arises. However, not all tourists have the same needs, and thus further segmentation is extremely important in order to identify each segment's needs and motivations at any given moment. Tourists' needs evolve constantly and differ considerably between individuals. Therefore, planners must adapt their offer constantly to meet tourists' needs, wants and expectations (Heather \& Gibson, 2002) according to their age, gender, lifestyle, education and income. As societies and their use of technology evolve, so do consumers' needs.

If young travellers' needs are examined in the light of Maslow's (1943) hierarchy of needs, a reversal can be observed in the hierarchy. The physiological needs (i.e. food, accommodation and water) are self-evident to these individuals, so these needs do not 
Tourism and Hospitality Management, Vol. 24, No. 1, pp. 197-211, 2018

A. Yousaf, I. Amin, J.A.C. Santos: TOURISTS' MOTIVATIONS TO TRAVEL: A THEORETICAL ...

always appear among the first priorities affecting their destination choices. Exoticism and places not linked with mass tourism are sought after by some types of young travellers, such as backpackers, but not all destinations can offer these conditions. However, as Millennials are concerned about their wellbeing and health, they are more likely to choose destinations that offer them adequate conditions to satisfy these needs.

Further studies focusing on Maslow's (1943) need for security are still needed to examine if young travellers have a different approach to security than other older tourists do. In general, security perceptions play an important role in tourism and travel (Williams \& Baláž, 2015), so a lack of security is considered a disadvantage for some destinations and/or countries and an advantage for others. This confirms the importance of Maslow's (1943) theory to understanding contemporary society.

For instance, Millennials value security when they travel. However, in some cases, riskseeking may be a motivation for youth travellers, as individuals in their early adulthood are often driven by a desire for adventure, experimentation and exploration (Gibson \& Yiannakis, 2002). Some backpackers and young adventure tourists look for risk and adventure to reinforce their identity or simply because of sensation seeking (Williams \& Baláž, 2015).

Maslow's (1943) third need in the motivational hierarchy is developing healthy relationships and forming relationships to create a sense of social belonging. This need is important to some groups of youth travellers, such as backpackers who travel together to experience a feeling of belonging to a group with the same characteristics and strengthen ties to other backpackers. Millennials, however, are much more independent, relying heavily on virtual contacts with online friends. These travellers depend on their peers' appreciation when forming their own opinions and making travel decisions, often using reviews as a crucial complement to decision-making (Veiga et al., 2017).

Maslow's (1943) theory helps explain how the importance of strong bonds with friends as a travel motivation has gained new dimensions in highly technological societies. Nonetheless, gaining familiarity with local communities in destinations and having valued experiences closely related to host communities has also become a quite important motivation for Millennials. This generation prefers to live close to or in residential areas, staying away from tourist resorts and seeking much closer contact with locals' way of living. In some cases, they get involved in volunteer tourism activities to contribute to a better world, also enjoying the recognition they get for their involvement in these. This is also true for Richards's (2015) global nomads, as discussed previously.

Maslow's (1943) fourth level of needs, namely, self-esteem, clarifies why people travel to impress friends, relatives and other social groups and gain higher social status, which is also extremely important to youth travellers. Millennials seek and require peer approval of their travel choices through the number of 'likes' their posts generate (Veiga et al., 2017). The more likes their travel narratives generate in social media networks, the more recognition they get and the stronger their self-esteem becomes. This is also clearly the case for the flashpackers category defined by Richards (2015). 
Tourism and Hospitality Management, Vol. 24, No. 1, pp. 197-211, 2018

A. Yousaf, I. Amin, J.A.C. Santos: TOURISTS' MOTIVATIONS TO TRAVEL: A THEORETICAL ...

Maslow's (1943) fifth level of needs deals with self-actualisation, which is quite evident among Millennials, as travel is considered a complement to education and a form of personal development, as mentioned previously. Millennials are aware of the importance of the environment, so they try to contribute to making a better world on an ecological level. This generation also appreciates cultures and landscapes, enjoying beauty and seeking to expand their understanding of the world.

Push and pull factors, as explained by Dann (1977), can further help planners to augment and enhance destinations' offers by enhancing pull factors that could include better prices, increased service quality and good infrastructure. The cited motivational theory provides marketers with a clearer grasp of which factors within their destination are important to travellers making destination choices. Since quality of service is regarded as a factor motivating tourists to travel, destination planners must be mindful of how they have to improve their service standards to attract travellers. In addition, the individual motivations of tourists need to be identified because, as Uysal et al. (2008) explain, a better understanding of travellers' motivations facilitates a more accurate segmentation of tourism markets. This, in turn, allows destination marketers to use their scarce resources more effectively.

The TCL model postulates that when tourists become more experienced, they seek to satisfy higher needs (Ryan, 1998). Consequently, these travellers' motivations change as they acquire more travel experience. However, different levels of experience alone cannot explain all tourist motivations as they also depend on socioeconomic, psychological, technological and demographic factors such as family size, education and longer average life expectancy (Tanrisever et al., 2016). Some authors have argued that, when education levels increase, travellers' demands also increase (Ceken et al., 2008; Tanrisever et al., 2016).

\section{CONCLUSIONS}

The present study's findings have implications regarding consumer motivations in tourism since all the discussed theories continue to be relevant and fresh applications have been repeatedly discovered. Among the most significant aspects are how individuals' desires, morals, benefits and outlooks can be used to understand travel motivations. These aspects thus should be taken into account when developing appropriate marketing strategies and suitable advertising appeals and formulating the best ways to segment markets and differentiate and position products.

The current research compiled and presented various motivational theories as a cohesive theoretical framework that can provide a better understanding of the reasons youths travel. This can help marketing managers and/or destination planners to strategise their offers. The application and understanding of these motivational models can facilitate market segmentation and channel marketers' approaches in more productive directions. The application of theories to practical knowledge can encourage the selection of only the best policies and long-term plans, which could add to value creation and improve the way the tourism industry functions and integrates its products. 
Tourism and Hospitality Management, Vol. 24, No. 1, pp. 197-211, 2018

A. Yousaf, I. Amin, J.A.C. Santos: TOURISTS' MOTIVATIONS TO TRAVEL: A THEORETICAL ...

Regarding the present study's second objective, namely, an analysis of youth tourism in the context of Maslow's (1943) hierarchy of needs, our study confirmed the validity of most of the cited author's propositions. However, some groups of young travellers may have different needs, which are not always prioritised in the same order as Maslow's (1943) hierarchy suggests. Because societies change rapidly and new needs have emerged - especially on a technological level or driven by technology - policymakers and tourism planners, as well as other stakeholders in destinations, must develop a greater awareness of youth travellers' needs. Planners need to react to this challenge with a strong presence on the Internet and in social media, implementing intelligent strategies that could function as new motivations for travellers from younger generations.

\section{REFERENCES}

Alexakis,G. (2011),"Transcendental leadership: the progressive hospitality leader's silver bullet", International Journal of Hospitality Management, Vol. 30, No. 3, pp. 708-713.

Ancuta, C., Olaru, M. \& Ianas, A. (2011), "The rural tourism in and its impact on local development in the mountainous Banat”. In Tourism and Economic Development, pp. 142-147.

Baloglu, S. \& Uysal, M. (1996), "Market segments of push and pull motivations: a canonical correlation approach", International Journal of Contemporary Hospitality Management, Vol. 8, No. 3, pp. 3238. doi: 10.1108/09596119610115989

Beard, J.G. \& Ragheb, M.G. (1980), "Measuring Leisure Satisfaction”, Journal of Leisure Research, Vol. 12, No. 1, pp. 20-33.

Beard, J.G. \& Ragheb, M.G. (1983), "Measuring Leisure Motivation”, Journal of Leisure Research, Vol. 15, No. 3, pp. 219-228.

Biswas, M. (2008), “Confirmatory Factor Analysis of Iso Ahola's Motivational Theory", An application of Structural Equation Modelling. In: Challenges Ahead, pp. 177-188.

Buffa, F. (2015), "Young Tourists and Sustainability. Profiles, Attitudes, and Implications for Destination Strategies", Sustainability, Vol. 7, pp. 14042-14062. doi:10.3390/su71014042

Çeken, H., Ateşoğlu, L., Dalgin, T. \& Karadă̆, L. (2008), “Turizm Talebine Bağlı Olarak Uluslararası Turizm Hareketlerindeki Gelişmeler”, Electronics Social Sciences Journal, Vol. 26, No. 7, pp. 71-85.

Cohen, E. (1972), "Who is a Tourist? A Conceptual Clarification", Sociological Review, Vol. 22, No. 4, pp. 527-555. doi: 10.1111/j.1467-954X.1974.tb00507.x

Cooper, H. (1984), The integrative research review: A systematic approach, Sage Publications, Beverly Hills.

Cooper, H. (1989), Homework, White Plains, Longman, NY.

Crompton, J.L. (1979), "Motivations for Pleasure Vacation”, Annals of Tourism Research, Vol. 6, No. 4, pp. 408-424. doi.org/10.1016/0160-7383(79)90004-5

Dann, G.M.S. (1977), “Anomie, Ego-Enhancement and Tourism”, Annals of Tourism Research, Vol. 4, No. 4, pp. 184-194. doi.org/10.1016/0160-7383(77)90037-8

Dann, G.M.S. (1981), "Tourist Motivation: An Appraisal”, Annals of Tourism Research, Vol. 8, No. 2, pp. 187-219. doi.org/10.1016/0160-7383(81)90082-7

Dionysopoulou, P. \& Mylonakis, J. (2013), "Youth tourists' profile and their travel choices as influenced by social media networks", European Journal of Hospitality and Tourism Research, Vol.1, No. 3, pp. 22-35.

Han, H., Kim, W. \& Kiatkawsin, K. (2017), “Emerging youth tourism: fostering young travellers' conservation intentions", Journal of Travel \& Tourism Marketing, Vol. 34, No. 7, pp. 905-918. doi: 10.1080/10548408.2016.1261758

Hills, J. M. M. (1965), The Holiday: A Study of Social and Psychological Aspects with Special Reference to Ireland, The Tavistock Institute of Human Relations, London.

Bizirgiannia, I. \& Dionysopoulou, P. (2013), "The influence of tourist trends of Youth Tourism through Social Media (SM) \& Information and Communication Technologies", Procedia - Social and Behavioral Sciences, Vol. 73, pp. 652-660.

Iso-Ahola, S.E. (1982), "Towards a Social Psychology Theory of Tourism Motivation: A Rejoinder", Annals of Tourism Research, Vol. 9, No. 2, pp. 256-262. doi.org/10.1016/0160-7383(82)90049-4

ITB (2016), "ITB World Travel Trends Report 2016 / 2017”, retrieved 26 December 2017 from https://www.itb-berlin.de/en/Press/Downloads/Publications/ 
Tourism and Hospitality Management, Vol. 24, No. 1, pp. 197-211, 2018

A. Yousaf, I. Amin, J.A.C. Santos: TOURISTS' MOTIVATIONS TO TRAVEL: A THEORETICAL ...

Klenosky, D. (2002), “The "Pull” of Tourism Destinations: A Means-End Investigation”, Journal of Travel Research, Vol. 40, No. 4, pp. 385-395.

Kotler, P. \& Keller, K.L. (2012), Marketing Management, $14^{\text {th }}$ ed., Pearson Prentice Hall, Upper Saddle River, NJ.

Li, M. \& Cai, A.L. (2013), “A sub cultural analysis of tourism motivations”, Journal of Hospitality \& Tourism Research, Vol. 40, No. 1, pp. 85-113.

Maslow, A.H. (1943), “A Theory of Human Motivation”, Psychological Review, Vol. 50, pp. 370-396.

Todorovi, N. \& Dobrica Jovicic (2016), "Motivational factors of youth tourists visiting Belgrade", CVIJIC Vol. 66, No. 2, pp. 273-289.

Pearce, P. L. (1988), “The Ulysses factor: Evaluating tourists in visitor's settings”, Annals of tourism research, Vol. 15, No. 1, pp. 1-28

Pearce, P. L. \& Lee, Uk-Il (2005), "Developing the travel career approach to tourist motivation", Journal of Travel Research, Vol. 43, No. 3, pp. 226-237.

Plog, S.C. (1974), "Why Destination Areas Rise and Fall in Popularity", Cornell Hotel and Restaurant Administration Quarterly, Vol. 14, No. 4, pp. 55-58. doi.org/10.1016/S0010-8804(01)81020-X

Richards, G. (2015), "The new global nomads: Youth travel in a globalizing world", Tourism Recreation Research, Vol. 40, No. 3, pp. 340-352, doi: 10.1080/02508281.2015.1075724

Ryan, Chris (1998), "The travel career ladder: an appraisal”, Annals of Tourism Research, 25, Vol. 4, pp. 936 957.

Santos, M, Veiga, C. \& Águas, P. (2016), "Tourism services: facing the challenge of new tourist profiles", Worldwide Hopitality \& Tourism Themes, Vol. 8, No. 6, pp. 654-669. doi: 10.1108/WHATT-092016-0048

Simková, E. \& Jindrich, H. (2014), "Motivation of Tourism Participants", Social and Behavioral Sciences, Vol. 159, pp. 660 -664. doi.org/10.1016/j.sbspro.2014.12.455

Snepenger, D., King, J., Marshall, E. \& Uysal, M. (2006), "Modelling Iso-Ahola's Motivation Theory in the Tourism Context", Journal of Travel Research, Vol. 45, No. 2, pp. 140-149.

Tanrisever, C., Pamukçu, H. \& Batman, O. (2016), New tourism trends in the world and their adaptations to Turkey. Gümüşhane Üniversitesi Sosyal Bilimler Enstitüsü Elektronik Dergisi, 7, pp. 55-72.

Um, S. \& Crompton, L.J. (1992), "The Roles of Perceived Inhibitors and Facilitators in Pleasure Travel Destination Decisions", Journal of Travel Research, Vol. 30, No. 3, pp. 18-25.

United Nations World Tourism Organization (UNWTO) (2016), “Annual Report 2016”, retrieved 26 December 2017 from http://media.unwto.org/publication/unwto-annual-report-2016

UNWTO Report (2016), "Travel and Tourism: Economic Impact 2016 World”, Accessed on 10 ${ }^{\text {th }}$ May, 2017 from

https:/www.wttc.org/media/files/reports/economic\%20impact\%20research/regions\%202016/worl d2016.pdf

Uysal, M. \& Jurowski, C. (1994), "Testing the push and pull factors", Annals of Tourism Research, Vol. 21, No. 4, pp. 844-846. doi: 10.1016/0160-7383(94)90091-4

Uysal, M., Li, X. \& Sirakaya-Turk, E. (2008), "Push-pull dynamics in travel decisions". In Haemoon Oh \& Abraham Pizam, Handbook of Hospitality Marketing Management, Taylor \& Francis, Abingdon, UK, pp. 412-439.

Veiga, C., Santos, M., Águas, P. \& Santos, J. (2017), “Are millennials transforming global tourism? Challenges for destinations and companies", Worldwide Hospitality and Tourism Themes, Vol. 9, No. 6, pp. 603-616.

Virdi, R. \& Traini, A. (1990), Psicologia del turismo. Turismo, salute, cultura, Armando Mondadori, Roma.

Williams, A.M. \& Baláž, V. (2015), "Tourism Risk and Uncertainty: Theoretical Reflections", Journal of Travel Research, Vol. 54, No. 3, pp. 271-287. doi: 10.1177/0047287514523334

World Tourism Organisation (2008), "Youth Travel Matters-Understanding the global phenomenon of youth travel", retrieved 26 December 2017 from

https://www.e-unwto.org/doi/book/10.18111/9789284412396 
Tourism and Hospitality Management, Vol. 24, No. 1, pp. 197-211, 2018

A. Yousaf, I. Amin, J.A.C. Santos: TOURISTS' MOTIVATIONS TO TRAVEL: A THEORETICAL ...

Anish Yousaf, PhD, Assistant Professor (Corresponding Author)

Rajalakshmi School of Business

Department of Marketing

Chennai, India

Phone: +91-8146453583

E-mail: anishyousaf86@gmail.com

Insha Amin, $\mathrm{PhD}$, Assistant Professor

Center for Hospitality \& Tourism

Baba Ghulam Shah Baadshah University, Rajouri

Jammu \& Kashmir, India

E-mail: inshamn@gmail.com

Jose Antonio C. Santos, PhD, Professor

University of Algarve

School of Management, Hospitality and Tourism

Faro, Portugal

E-mail: jasantos@ualg.pt

Please cite this article as: Yousaf, A., Amin, I., C. Santos, J.A. (2018), Tourists' Motivations to Travel: a Theoretical Perspective on the Existing Literature, Tourism and Hospitality Management, Vol. 24, No. 1, pp. 197-211, 010403, https://doi.org/10.20867/thm.24.1.8

\section{(c) (1) (9)}

Creative Commons Attribution - Non Commercial - Share Alike 4.0 International 